\title{
FORMS OF POLITICAL AND PARA-MILITARY YOUTH ENROLLMENT IN ROMANIA. CASE SURVEY: THE COUNTRY'S SENTINEL (STRAJA ȚĂRII) 1934-1940
}

\author{
Sorin RADU \\ University from Sibiu/Romania
}

RESUMEN: La historiografía rumana no se ha acercado de una manera coherente y consistente a la cuestión de los movimientos juveniles y a las formas de encuadramiento de la juventud del siglo XX; estos temas quedaron marginados por la historiografía comunista. La organización El Centinela del Pais (Straja Tãrii) no fue investigada durante el régimen comunista en Rumania, probablemente debido a que presenta muchas similitudes con la organización de los comunistas pioneros. Después de que el régimen comunista se derrumbara en 1989, los historiadores se han acercado a otros temas considerados más importantes.

La única excepción ha sido la organización de la Legión del Arcángel Miguel (el Movimiento Legionario), de ideología de extrema derecha, que también desarrolló una estructura de encuadramiento de la juventud y ha sido muy investigada por historiadores rumanos y del resto de Europa. El presente estudio tiene la intención de ofrecer una presentación panorámica de la organización juvenil El Centinela del País, insistiendo en las causas de su constitución, su organización y las modalidades de formación y adoctrinamiento de los Centinelas. Esta organización tenía por un lado el objetivo político e ideológico de atraer a los jóvenes de Rumania, debido a la necesidad del Estado de ofrecer una alternativa a la propaganda de extrema derecha; principalmente del Movimiento de los Legionarios de Cristo, que era muy atractivo para los jóvenes. Por otro lado, buscaba mantener el régimen personal del rey Carlos II, jugando un papel importante dentro de la propaganda y la formación del culto a su personalidad

PALABRAS CLAVE: Rumania, El Centinela del País, el rey Carlos II, la adscripción de jóvenes.

ABSTRACT: So far, the Romanian historiography has not approached, in a coherent and consistent manner, the issue of youth movements, forms of regimentation of the 20th century youth, these subjects being marginalized by the communist historiography. The Country's Sentinel (Straja Țării) remained unexplored during the communist regime in Romania, probably also because it presented too many similarities with the communist pioneers' organization. After the Communist regime collapsed in 1989, historians have approached other issues, considered to be more important. The only exception has been the organization The Legion of the Archangel Michael (the Legionary Movement), extreme-right oriented, which also developed a youth regimentation structure, and has been consistently investigated both by Romanian historians and historians from Europe and elsewhere.

The present survey intends to offer a panoramic presentation of the youth organization "The Country's Sentinel", insisting upon the causes of its establishment, its organization and the modalities of training and indoctrinating the Sentinels. The survey advances the idea that this organization had the aim

${ }^{1}$ Recibido el 6 de septiembre de 2011. Aceptado en el consejo de 8 de noviembre de 2011. 
of politically and ideologically enroll Romania's youth, on the one hand, due to the State's necessity to offer an alternative to the far-right propaganda (mainly of the Legionary Movement), which appeared very attractive to young people, and on the other, in order to sustain the personal regime of King Charles II, playing an important part within the propaganda and the shaping of his own personality cult.

KEYWORDS: Romania, The Country's Sentinel, King Charles II, youth enrollment.

\section{THE HISTORIOGRAPHY OF THE ISSUE ${ }^{2}$}

So far, Romanian historiography has not approached, in a coherent and consistent manner, the issue of youth movements, the forms of enrollment of the 20th century youth, these subjects being marginalized by the Communist historiography. "The Country's Sentinel" (Straja Țării) remained unexplored during the Communist regime in Romania, probably also because it presented too many similarities with the Communist pioneers' organization. After the Communist regime collapsed in 1989, historians have approached other issues, considered to be more important. The only exception has been the organization the Legion of the Archangel Michael (the Legionary Movement), extreme-right oriented, which had also developed a youth enrollment structure, and has been consistently investigated both by Romanian historians ${ }^{3}$ and historians from Europe and elsewhere ${ }^{4}$.

2 The present article is based on the paper delivered at the international scientific conference in Pécs (Hungary), on December $4^{\text {th }}-5^{\text {th }} 2009$, on the topic "State Youth Organizations and Youth Organizations of the German Minorities in South East Europe", organized by Die Stiftungsprofessur für Deutsche Geschichte und Kultur im südöstlichen Mitteleuropa des Historischen Instituts der Universität Pécs.

${ }^{3}$ ORNEA, Z. (1995). Anii treizeci. Extrema dreaptă românească. (The 1930s.The Romanian Farright Wing) Bucureşti: Fundația Culturală Română; PETCulescu, Constantin (1997). Mişcarea legionară. Mit şi realitate. Bucharest: Editura Noua Alternativă; ZAMFIRESCU, Dragoş (1997). Legiunea Arhanghelului Mihail de la mit la realitate (The Legion of Archangel Michael from Myth to Reality). Bucharest: Editura Enciclopedică; BELDIMAN, Dana (2002). Armata şi Mişcarea Legionară 1927-1947 (The Army and the Legionary Movement 1927-1947). Bucharest: Institutul Naţional pentru Studiul Totalitarismului (The National Institute for the Study of Totalitarianism);

${ }^{4}$ VeIGA, Francisco (1993). Istoria Gărzii de Fier. 1919-1941. Mistica ultranaționalismului (The History of the Iron Guard 1919-1941. The Mystique of Ultranationalism). Bucharest: Editura Humanitas; VolovicI, Leon (1995). Ideologia naționalistă şi „problema evreiască”. Eseu despre formele antisemitismului intelectual în România anilor '30 (The Nationalist Ideology and "the Jewish Problem". An Essay upon the Forms of Intellectual Anti-Semitism in Romania in the 1930s). Bucharest: Editura Humanitas; MutTI, Claudio (1995). Mircea Eliade şi Garda de Fier (Mircea Eliade and the Iron Guard). Sibiu: Editura Puncte Cardinale; NAGY-TALAVERA, Nicolas, M. (1996). $O$ istorie a fascismului în Ungaria şi România (A History of Fascism in Hungary and Romania). Bucharest: Editura Hasefer; LIVEZEANu, Irina (1998). Cultură şi naționalism în România Mare 19181930 (Culture and Nationalism in Great Romania). Bucharest: Editura Humanitas; HeInEN, Armin 
Regarding "The Country's Sentinel” (Straja Țării), there is a true historiographic gap, as the organization has been investigated only tangentially, within general works on the political life between the two World Wars, especially works dedicated to King Charles II $^{5}$. Research is more difficult because of the inexistence of a documentary fund within the National Archives of Bucharest regarding "The Country's Sentinel", or in any of the county archives. Information about this organization is scattered through various archival funds, thus making the research process very hard.

The present survey intends to offer a panoramic presentation of the youth organization "The Country's Sentinel", insisting upon the causes of its establishment, its organization and the modalities of training and indoctrinating the Sentinels. The survey advances the idea that this organization had the aim of politically and ideologically enroll Romania's youth, on the one hand, due to the State's necessity to offer an alternative to the far-right propaganda (mainly of the Legionary Movement), which appeared very attractive to young people, and on the other, in order to sustain the personal regime of King Charles II, playing an important part within the propaganda and the shaping of his own personality cult.

\section{FORERUNNERS OF THE SENTINELS IN ROMANIA}

In the late $19^{\text {th }}$ and early $20^{\text {th }}$ century, Europe witnessed the emergence of a number of organizations, most of them created of private initiative, in which young people were free to enroll according to their interests and aspirations (The Scout Movement in Great Britain or The Socol Movement in the Austrian-Hungarian Empire). Between the two World Wars, youth became a target group for the governments of various countries, especially those where the ascent to totalitarianism was obvious. The enthusiasm and energy of youth, as well as their naivety were speculated by political parties and the authorities [see especially the case of The Youth Organization of the German National Socialist Party -

(1999). Legiunea "Arhanghelul Mihail”. O contribuție la problema fascismului internațional (The Legion "Archangel Michael". A Contribution to the Issue of International Fascism). Bucharest: Editura Humanitas; VAGO, Bella (2003). Umbra svasticii. Naşterea fascismului şi antisemitismului în bazinul Dunării (1936-1939) (The Shadow of the Swastika. The Birth of Fascism and Anti-Semitism in the Danube Basin (1936-1939)). Bucharest, Editura Curtea Veche.

${ }^{5}$ SCURTU, Ioan (2004). Carol al-II-lea (Charles II). Bucharest: Editura Enciclopedică; SCURTU, Ioan (1991). Monarhia în România 1866-1947 (Monarchy in Romania 1866-1947). Bucharest: Editura Danubius; AleXAndrescu, Sorin (1998). Paradoxul roman (The Romanian Paradox). Bucharest: Editura Univers; BRUJA, Radu Florian (2006). Carol al-II-lea şi partidul unic, Frontul Renaşterii Naționale (Charles II and the Single Party, the Front of National Rebirth). Iaşi: Editura Juminea. 
Hitlerjugend or those of The Italian Fascist Party - Opera Nazionale Balilla (National Organisation of the Balilla), Avanguardisti (The Fascist Youth Forefronts)]. Taking these youth organizations as a model, in the late $19^{\text {th }}$ and early $20^{\text {th }}$ century, there were a number of associations based in Romania, with regional activity, gathering school-aged youth, trying to prepare them for life through cultural and sporting activities. The best known through their work were the associations: "Oltenii Voinici" (The Brave Walachians), "Micii Dorobanți" (The Little Soldiers) (1877), "Arcaşii Bucovinei” (Bukovina's Archers) (1905), "Asociația Creştină a Tinerilor" (The Christian Youth Association) (1919), "Şoimii României" (Romania's Falcons) (1927), "Şoimii Carpaților" (The Carpathian Falcons) (1928) $)^{6}$.

The most important organization of youth enrollment on a national level was founded in 1914 and named "Romania's Scouts". The establishment of Scouts in Romania was part of the world trend at that time and drawing on the model created by Lord Robert Stephenson Smyth Baden-Powell, who initiated an original education program based on games, hiking, outdoor camp life in a community of comrades. Scouting taught youth to collaborate, socialize and participate in charitable and voluntary activities ${ }^{7}$. In general, children were co-opted into the organization between 11 and 18 years of age. Church, school and parents were seen as major contributors of the Scout Movement, but the State was not supposed to interfere with the organization ${ }^{8}$. In terms of its method of work, scouting dealt with the individual education of the child, completing school, aiming at the comprehensive development of the individual's personality ${ }^{9}$. Scouting developed the youth's sportsmanship, sense of mutual help, responsibility, sense of observation and orientation, love towards nature, moderation, etc. Young people would also learn to be moral, industrious, courageous under all circumstances, solidary and patriotic ${ }^{10}$.

${ }^{6}$ GABREA, Iosif (1936). Şcoala şi străjeria în pregătirea tineretului (School and the Sentinel in the Instruction of Youth). Bucharest: Editura Bucovina, pp. 16, 17.

${ }^{7}$ PeTRESCU, I.M. (1915). Ce trebuie să ştie şcolarii şi părinții lor despre cercetăşie. Manual de informațiuni şi propaganda ideilor şi doctrinei cercetășeşti (What School Students and Parents Should Know about Scouting. A Textbook of Information and the Propaganda of Scouts' Doctrine and Ideas). Craiova: Editura Scrisul Românesc, p. 55.

${ }^{8}$ GoIA, A.S. (1933). Cartea cercetaşului practic. (The Book of the Practical Scout), vol. I. Cluj: Imprimeria Fondul Cărților Funduare, pp. 1, 2.

${ }^{9}$ SiRCA, L. (1937). Cercetăşia în cadrul curentelor contemporane de pedagogie (Scouting within Contemporary Pedagogical Trends). Deva: Tipografia Decebal, p. 10.

10 (1919). Programul de lucru al cercetaşilor (The Scouts' Work Program). Bucharest: Tipografia Jockey Club, pp. 111-126. 
During Romania's involvement in World War I (1916-1918), the organization "Romania's Scouts" engaged in various actions in support of the state authorities, filling in for those who had gone to the front, working in hospitals, canteens, etc., running various errands within postal services, etc. helping to supply the army etc. 11

After World War II, scouting entered a period of decline, being integrated in the Cultural Foundation "Prince Charles" between the years 1924 and 1929, and passing under the authority of the National Office of Physical Education after 1929. In 1932 King Charles II became commander of the Association "Romania's Scouts", and he decided its inclusion into the organization "The Country's Sentinel" by a 1937 Royal Decree. ${ }^{12}$.

\section{FOUNDATION AND ORGANIZATION}

"The Country's Sentinel" emerged in a complex political context, marked by the deep economic crisis existent in Romania, corruption, as well as the effervescence of right and far-right political trends. We should mainly note the youth activities undertaken by the Legionary Movement, led by Corneliu ZeleaCodreanu, which was outlawed in December 1933, but which started to function legally from 1934, under the name of the Party "Everything for the Country" ("Totul pentru țară"). After 1933, the conflict between the Legionaries and King Charles II (Annex No.1) had already sharpened and become public ${ }^{13}$.

In this context, the question of organizing young people, who had been neglected for years by the State, became pressing for the King. A first step in this regard was made on the 9th of May, 1934, by the foundation of the Office for the Education of Romanian Youth. The purpose of this institution was to manage and control the activities of all the organizations which aimed to educate young men and women, aged 7 to 18 , following a unitary program. The second step was made

${ }^{11}$ DAIA, Alexandru (1981). Eroi la 16 ani. Jurnal de război (1916-1918) (Heroes at 16. A War Log (1916-1918)). Bucharest: Editura Ion Creangă, pp. 185, 276-278.

${ }_{12}$ Enciclopedia României (Encyclopedia of Romania), (1938), vol. I. Bucharest, pp. 484-485.

13 See extensively: VeIGA, Francisco (1993). Istoria Gărzii de Fier 1919-1941. Mistica ultranationalismului (The History of the Iron Guard 1919-1941. The Mystique of Ultranationalism). Bucharest: Editura Humanitas, pp. 183-236; HeINEN, Armin (1999). Legiunea „Arhanghelul Mihail”. $O$ contribuție la problema fascismului internațional (The Legion "Archangel Michael". A Contribution to the Issue of International Fascism). Bucharest: Editura Humanitas. 
on the 1st of September, 1934, through the establishment of "The Country's Sentinel” ("Straja Țării”) organization ${ }^{14}$.

The King and his acolytes believed that the foundation of "The Country's Sentinel" was justified by the government's instability that was reflected out on the streets and influenced young people, thus creating a fertile ground for the Legionary propaganda. Charles II's plan was very clear and simple: by the establishment of the Country's Sentinel, youth had to be taken away from the influence of the Legionary leader Corneliu Zelea Codreanu and directed towards the adulation of the King. The marks of the Sentinels were clearly fascist: the outstretched arm salute, the uniforms, the parades, the paramilitary training, the leader principle (Fürehrprinzipe), the cult for the head of State. Prime Minister Gheorghe Tătărescu admitted to the fact that, by establishing this organization, as well as by the paramilitary training that the Sentinels undertook, young people were controlled and trained to be future soldiers ${ }^{15}$.

Nevertheless, "The Country's Sentinel" was an autonomous institution for the guidance and education of youth, being directly coordinated by Charles II. The propaganda presented the creation of this organization as proof of the King's profound interest in young people, as he desired to take them away from the dives, taverns and the street ferment. According to the official propaganda, the youth was growing up without any ideal, subject to morbid manifestations. "The Country's Sentinel" could save them from this deviation and perversion, by actively involving young people in society. The King considered "The Country's Sentinel" as a nursery and school for practical life, where they practiced solidarity among each other and developed working and active living skills. Furthermore, the Sentinels practiced sports in order to help strengthen the biological race and to obtain a higher body immunization against disease. The Sentinels had to represent a model of behavior both for the young and for adults, an example of order and discipline. In 1936, the King stated that the Country's Sentinels had to become a "movement of national regeneration", and Sentinels had to be educated to become good citizens and perfect patriots ${ }^{16}$. The resemblance with the Legionary Movement was quite obvious.

${ }^{14}$ Sidorovici, Teofil Gh., EnESCu-BugheA, C. (1937). Straja Țării. O credință şi un avânt (The Country's Sentinel. Faith and Impetuosity. Bucharest, p. 18-19; (1938). Encyclopedia of Romania, vol. I. Bucharest, p. 483.

15 TĂTĂRESCU, Gheorghe (1996). Mărturii pentru istorie (Testimonies for History). Bucharest: Editura Enciclopedică, p. 159.

${ }^{16}$ Sidorovici, Teofil Gh., EnESCu-BugheA, C. (1937). Straja Țării. O credință şi un avânt (The Country's Sentinel. Faith and Impetuosity). Bucharest, pp. 18-22. 
Although "The Country's Sentinel" was organized according to the principles of other fascist youth organizations from Europe, Charles II claimed it was a pure Romanian creation. He rejected the comparison with the Italian organization Balilla, because "The Sentinel" was not a military formation. It did not resemble the Hitlerjungend organization either, because it did not lead a state policy (sic!). Finally, the organization neither resembled the Czechoslovak Socols, as the sportive side of the Sentinels was only secondary. Straja Țării (The Country's Sentinel) was, in fact - according to the King - a school of citizens and a socialmoral school, in the scout spirit of Baden-Powell, also having a national mystic atmosphere about it. The King considered that the purpose and the methods of "The Country's Sentinel" were different from those of fascist organizations ${ }^{17}$. “... The Sentinel - King Charles II declared - is specific to Romania; [...] the Sentinel will be permanently checking the educational potential, in terms of practice, and the training of our youth"18. Moreover, the King stated that the Sentinel "inculcates youth with moral precepts, the cult for the dead and the respect for work [...] it is a school without cold walls, without a teacher's desk, or grades, or grade book, without desks to immobilize the first childhood [...] a live school of character" ${ }^{\prime 1}$. The leader of the Sentinel, Teofil Sidorovici (Annex No.2), reinforced the King's words, saying that: "In the Country's Sentinel we are more than Sentinels, we are a new sect, and we are fanatics in the most beautiful and sublime sense, for the Nation, Country and King. We pledge to stay Sentinels to the end of our lives, no matter what ${ }^{\prime 20}$.

The public personalities in Romania had different opinions regarding the establishment of "The Country's Sentinel" organization. The politicians sharing democratic views, such as the leaders of the National-Peasant Party, Iuliu Maniu and Ion Mihalache, or the leader of the National Liberal Party, Dinu Brătianu, showed great suspicion related to the royal plans of enrolling youth. In stead, among the right-wing politicians these ideas tended to be accepted. In his memoirs, Nichifor Crainic claims the paternity of the idea of creating the Sentinel ${ }^{21}$. A very well-known right-wing journalist, Pamfil Şeicaru, appreciated the King's plan to

17 “Curentul” (“The Trend"), Bucharest, February 22 $2^{\text {nd }} 1938$, p. 3.

${ }^{18}$ The Central National Historical Archives, Bucharest, the Royal House Fund, file 43/1936, f. 56.

19 The Central National Historical Archives, Bucharest, the Ministry for National Propaganda the Intelligence Service Fund, file 673, f. 22

20 "România" ("Romania”), Bucharest, January $13^{\text {th }} 1939$, p. 5.

${ }^{21}$ CRAINIC, Nichifor (1991). Zile albe, zile negre. Memorii (White Days, Black Days. Memoirs). Bucharest: Casa Editorială Gândirea, p. 264. 
take youth away from the Legionary influence and enroll them into „The Country's Sentinel"22. Later on, Horia Sima, the Commander of the Legionary Movement, would share the same opinion ${ }^{23}$.

Unofficially, "The Country's Sentinel" was called "The King's Guard" or "The White Army". Joining the organization was compulsory for girls aged 7 to 21 and boys between 7 and 18. The organizational structure was the following: the Nest (formed of six members, was the basic Sentinel unit; the Century (a unit corresponding to a class of school students); the Troop (comprising all the centuries in a school); the Cohort (subordinated the Sentinel units from the towns and villages of a county. Bucharest had four cohorts, corresponding to the four administrative sectors); the Legion (subordinated all the Sentinel units in a county); Territorial Commandments (which were the commanders' initiation and training centers). The Sentinels above 12 years of age made a promise towards the movement, and those aged between 12 and 18 were tied to the organization by an oath. The young people between 18 and 21 took an oath of faith towards the King. The official day of the Country's Sentinel was set to be the 8th of June, the same date when the King had been crowned, and the Sentinel's Hymn was the song Trei culori (The Three Colors), signed by the national composer Ciprian Porumbescu. The organization's propaganda slogan was: "Faith and Labor for the Country and the King". The Sentinels greeted by saying "Gesundheit!" ("health", t.n.), a greeting also used by other organizations. The Sentinels' uniform consisted of a white shirt, ultramarine three-quartered trousers or skirt for the girls. The equipment was completed with a cloak, a white beret and a tie in the color specific to the region that the Sentinel unit belonged to. Uniforms varied depending on the season, the activities performed or the ranks of the Sentinels. Starting with September 1st 1938, the Sentinel uniform became compulsory for all school students. The supreme leader, the "Great Sentinel" ("Marele Străjer"), was King Charles II, and the second rank commander was Teofil Sidorovici, who was close to the King. All of the major leading positions with the Sentinels were occupied by members of the royal camarilla, or by people close to Prime Minister Gheorghe

22 ŞEICARU, Pamfil (2000). Istoria Partidelor Național, Țărănist şi Național-Țărănist (The History of the National, Peasant and National-Peasant Parties). Bucharest: Editura Victor Frunză, p. 134.

23 SimA, Horia (2003). Istoria Mişcării Legionare (The History of the Legionary Movement). Bucharest: Editura Metafora, pp. 274-276. 
Tătărescu. The most important governing body was the Superior Guidance Council (Consiliul Superior de Îndrumare) $^{24}$.

There were two distinct periods in the evolution of the Country's Sentinel: I. 1934-1937, when the Sentinel developed in a slow step on a county level, in spite of the support offered by the State; II. 1938-1940, the period of the authoritarian monarchy, when the Sentinel of the Country was marked by the strict control of the State, obliging the young to enroll as Sentinels and overloading the training program.

In August 1934 an experimental center for the training of trainers was established at Breaza (Prahova County). The first experimental group was trained in Breaza between the 1st and the 13th of September 1934, and consisted of 25 male and 24 female teachers from Bucharest. The training program lasted for 25 days $^{25}$. In the subsequent years two centers for the training of trainers were created: at Sfântul Gheorghe and Predeal.

In a first phase, the Sentinel was introduced as an experimental model in 10 counties and about 600 students were taken to Breaza (the Prahova County) for training. Being superficially applied, the Sentinel had the effect of a cheap imitation; therefore, at the end of 1936, "The Country's Sentinel" was not at all represented in more than half of the counties. At the end of 1937 it worked superficially in 30 counties. Only in 1938 would it expand throughout the country, due to the stringent measures imposed by the authorities. For example, starting with 1937, all students attending private and state schools were obliged to go through the Sentinel program (Annex No.3). Moreover, factory owners were also forced to enroll their apprentices into "The Country's Sentinel". By 1938 "The Country's Sentinel" had incorporated all of the youth organizations existing in Romania (Romania's Scouts, The Archers, The Carpathian Falcons - Cercetaşii României, Arcaşii, Şoimii Carpaților), and the Sentinel uniform was required in all schools. Teachers were also obliged to participate in training courses organized in permanent or temporary centers active during the summer. The number of the

${ }^{24}$ Sidorovici, Teofil Gh., Enescu-BugheA, C. (1937). Straja Țării. O credință şi un avânt (The Country's Sentinel. Faith and Impetuosity). Bucharest, pp. 139, 140; STRECOvSCHI, Toma I. (1939). Cuibul străjeresc. Contribuții (The Sentinels' Nest. Contributions). Bucharest, pp. 24-27; RĂDUlescu-Zoner, Şerban (2003). A fost un destin. Amintiri, mărturii, dezvăluiri (It Was Destiny. Memories,Testimonies, Revelations). Bucharest: Editura Paideia, p. 47.

25 “Straja Țării - Buletin” (“The Country’s Sentinel - Bulletin), no. 1-2, 1940, p. 66. 
Country's Sentinel members increased substantially during the years of the authoritarian monarchy 1938-1940, being directly financed by the State ${ }^{26}$.

Young people above the age of 18 were integrated into the pre-military, a service that allowed boys to practice shooting, while being closely monitored by the authorities. In 1939 students were enrolled into the Social Service. Gathered in summer camps, students were required to comply with an ideological education and to participate in parades and marches, glorifying the $\mathrm{King}^{27}$.

\section{THE SENTINEL PROGRAM}

The Sentinel doctrine placed an important stress upon collective active life and a lot of practical work, borrowing from the scouts the principles of social solidarity, developing moral skills in the daily routine, developing the civic sense etc. However, beyond copying the scout-specific methods, their practical application and the training of Sentinels were deficient, adding to formalism the awkwardness experienced by both Sentinels and their commanders, due to their being permanently supervised, followed, controlled. The Sentinel program was designed by taking into consideration the Sentinels' age, the different seasons and the specific region. In autumn, the Sentinels worked in workshops and farming, in winter they prepared the artistic program for the holidays, raised funds for the poor and participated in winter sports competitions organized among the regions. In spring they started work on the field again, they volunteered to repair the roads, declog the ditches, prove maintenance for schools and churches etc. Summer began with the participation to the "Restoration" celebration ${ }^{28}$. The preparations for this very important event, which overlapped with the Sentinel day, began in February, when guide booklets were sent to schools in order to be purchased; they contained

\footnotetext{
${ }^{26}$ Sidorovici, Teofil Gh., EnESCU-BugheA, C. (1937). Straja Țării. O credință şi un avânt (The Country's Sentinel. Faith and Impetuosity). Bucharest, pp. 80-82.

27 The Central National Historical Archives, Bucharest, the Ministry for National Propaganda the Intelligence Service Fund, file 673, ff. 124-126.

${ }^{28}$ After Prince Charles of Hohenzollern's return to the country, on June $8^{\text {th }} 1930$, Romania's Parliament decided the annulment of the laws of January $4^{\text {th }} 1926$ (which proclaimed Prince Michael, King Ferdinand's grandson as King - in the context of his father, Prince Charles' willingly renouncing the throne and leaving the country) and the proclamation of Charles as King, under the name Charles II. This event remained in Romanian history as the "Restoration".
} 
songs and overall exercises that were to be executed during demonstrations ${ }^{29}$. The months July and August were reserved to Sentinel camps ${ }^{30}$.

The Sentinel curriculum allocated 30 annual meetings for training. A meeting summed 7 hours. Annually the Sentinel had 210 hours of class. The courses took place in schools and besides Geography, History, Hygiene and military training, students also had a theoretical educational program within which students would learn about: the purpose and the organization of "The Country's Sentinel", the functioning of the Sentinel units, the attributions of the commanders, the role of the Social Service etc. Practice was much more important than theory. In the years 1934-1935 Sentinel classes were not included in the curriculum. Therefore, the Sentinel activity was included in the extra-curricular activities, and teachers had to do voluntary work. Thus, Sentinel training overloaded the teachers' program. The fact that they were not paid for the overtime classes made teachers disinterested in these activities. Starting with 1935, Thursday was declared the Sentinel's day. The students' program was also overloaded (they used to spend 10 hours at school), bringing about parents' discontent ${ }^{31}$.

In 1936 "The Regulations of Camps and Colonies" were attached to the Sentinel curricula, including rules on: preparation, installation, organization, working program and the conduct of Sentinels inside the camp. The extension of the Sentinel program by setting up summer camps was not a novelty. Saxons and Legionaries combined relaxation with volunteer work in their own camps. The Sentinel program was not original, as alleged by Charles II, it was in fact a synthesis of the programs of all existing youth organizations, many of the activities being already performed by Scouts, Archers, Falcons and even Legionaries. The camp ceremony included activities such as organizing social evenings, artistic programs (with the theme of worshipping the King), gymnastics, sports (especially shooting practice, athletics, and field orientation), organizing trips to visit tourist attractions with historical significance, attending religious services at churches close to the camps. The camp program also included community service work (volunteer work): roads and fences repairs in villages, maintenance of cultural

29 Buhman, A.E. (2006). Patru decenii în serviciul Casei Regale a României. Memorii. 18981940 (Four Decades in the Service of the Royal House of Romania. Memoirs). Bucharest. Editura Sigma, pp. 397-407.

${ }^{30}$ ŞOIMESCU, Ştefan (1939). Pe drumurile reînoirii (On the Path of Renewal). Bucharest: Editura Bucovina, p. 63; Sidorovici, Teofil (1939). Brazdă nouă (A New Furrow). Bucharest: Tiparul Oltenia, p. 56.

31 "Straja Țării - Buletin" (“The Country's Sentinel - Bulletin”), no. 9-10, 1939, p. 40; "Solia Străjerului" ("The Sentinel's Mission”), Bucharest, no. 7, 1940, p. 7. 
centers, etc. The average duration of camps was 20 days and the necessary number of participants was 60-100 Sentinels. In reality, documents show that the number of those who participated in such camps did not exceed $40^{32}$.

In 1937 the Sentinel's week was introduced in the Sentinel curriculum. The curriculum had a series of attached annexes that presented the standard type of meeting, the required models of songs and dances to be included in the festivals organized throughout the year. In subsequent years, the curriculum diversified, the Sentinels were forced to participate in different circles depending on their proven skills. The Sentinel's Notebook (Annex No.4) also appeared and it contained, apart from the activities to be carried out daily, some practical advice on first aid, use of medicines from the Sentinel pharmacy, useful literature in Sentinel training, information on hygiene, a few Sentinel songs, etc. The duty of the Sentinels was to consult this book whenever they encountered difficulties / questions about the rules to be observed. The good deeds of Sentinels were also recorded within ${ }^{33}$.

On September 1st 1939, the Sentinel program was added another Sentinel day Saturday. The Sentinel program was drawn up for each Saturday by the troop commander, in collaboration with the school, the century commanders and the teachers who helped to run the program. Saturday, like Thursday, started with group refreshing drills, the report and then the inspection of the Sentinels' posture and body hygiene. The program continued with specific activities, mentioned above, usually accompanied by folk dance performance and patriotic songs, many of them in adulation of Charles II. It is interesting to note that Voivode Michael, the King's son, also participated in the program every Thursday ${ }^{34}$.

"The Country's Sentinel" regularly organized competitions on various subjects among the Sentinels, the best of them being rewarded, music circles, model airplane flying, Marine, physical education, etc. Starting from 1935, every Thursday, the Romanian Radio Company broadcast for one hour a Sentinel propaganda program - "The Sentinels' Hour" (Annex No. 6). From April 1938 the program was extended to 90 minutes. Schools were encouraged to prepare artistic programs, social evenings and present them on the radio within "The Sentinels'

32 ŞOIMESCU, Ştefan (1940). Doctrină, metodă sau curent de viață?(Doctrine, Method, or Life Trend?). Bucharest, pp. 34-36; EnEscu-BugheA, Constantin (1936). Sunt străjer! ... Cartea năzuințelor străjereşti (I Am A Sentinel!... The Book of the Sentinels'Aspirations). Bucharest: Tipografia „Universul”, p. 101.

33 "De Strajă" ("Sentinel”), Bucharest, no. 7-8, 1939, p. 39.

34 (1940). Straja Ţării - cinci ani de activitate (1935-1940) (The Country's Sentinel. Five Years of Activity (1935-1940)). Bucharest: Editura Cartea Românească, p. 145. 
Hour" ${ }^{35}$. This program aimed at educating the young generations in the spirit of adulation of the "Savior" Charles II. Prominent figures of the Romanian culture, such as Constantin Rădulescu-Motru, were invited at "The Sentinels' Hour" to speak in favor of the King and the Country's Sentinel.

"The Country's Sentinel" was financed by the State through grants awarded by ministries, provinces (a territorial-administrative structure that included several counties, imposed in Romania by the administrative reform of 1938), municipalities, communes, the kings of the state. For example, counties, municipalities and rural and urban communes were required to include in their annual budgets grants for the Sentinels equal to at least $0.5 \%$ of their respective budget. Municipalities, state institutions in general, had to provide all the necessary facilities for carrying out the activities of the Sentinels. The Ministry of Health provided healthcare to Sentinel work camps, and The Country's Sentinel, in general, by assigning doctors. The girls from "The Country's Sentinel" were trained by the Red Cross within special courses to provide medical care to the sick or injured in times of peace or war. An important activity of the Sentinels was the reforestation of some areas. In this respect, Forestry Departments were required to provide the necessary seedlings. The King imposed the collaboration between the Country's Sentinel and the Ministry of Education ${ }^{36}$.

The Sentinel project was enforced through the schools; teachers became Sentinel commanders, and students, important pawns of the movement. During the authoritarian monarchy ${ }^{37}$, sports clubs were obliged to assist the Sentinels in organizing their sports training, and put their sports facilities at the disposal of "The Country's Sentinel". Furthermore, the army was directly involved, assigning officers to "The Country's Sentinel" camps, in order to ensure an efficient military training program and to organize parades. An interesting collaboration developed with the cultural institutions of Romania, especially with theatres and cinemas. Professionals of these institutions were urged to assist the Sentinels in organizing

35 Denize, Eugen (1999), Istoria Societății Române de Radiodifuziune (The History of the Romanian Radio Society), vol. I, part I. Bucharest: Editura Casa Radio, p. 100.

${ }^{36}$ MoISESCU, D.N. (1938). Şcoală veche şi şcoală nouă (Old School and New School). Bucharest: Editura Cultura Românească, p. 20.

37 The authoritarian monarchy regime (January $10^{\text {th }} 1938$ - September $6^{\text {th }} 1940$ ) was established through a coup d'etat by King Charles II, who assumed the position of head of state, subordinating all state institutions after introducing the February 1938 Constitution. The Carlist Regime - as it is also known in history - was characterized by the banning of political parties, repressive measures against the opposition, especially the Legionaries, imposing a state of siege, censorship, and developing the personality cult. 
artistic performances, having as a topic the King's personality cult, especially after 1937 (Annex No. 5). At the same time, the Sentinels would regularly watch propaganda films about the King's activities, and also about the activities of other youth organizations from Europe ${ }^{38}$.

As early as 1935, "The Country's Sentinel” established formal working relationships with similar organizations in neighboring countries, particularly France, Yugoslavia, Poland and Czechoslovakia. In 1937 "The Country's Sentinel” started to establish closer connections with youth organizations in Germany and Italy $^{39}$.

Concerning the evolution of the Sentinel contingent, a serious increase was recorded: in 1934 there existed over 90,000 Sentinels, and in 1940 approximately 4,373,039; apart from these, there were 44,875 commanders and 36,150 extraschool Sentinels ${ }^{40}$. This considerable increase can be explained by youth's as well as teachers' obligation to enroll in "The Country's Sentinel", which, thus, had become a mass organization.

\section{CONCLUSIONS}

The compulsory character and the authorities' excessive control had adverse effects to what the king had expected. Students, pre-military, Sentinels as a whole, showed disregard towards and distanced themselves from the Sentinels' movement. In the years 1938-1940, formalism became constant during the demonstrations organized by the leaders of The Country's Sentinel. Town Hall citations, fines and the police force were necessary in order to bring young people to pre-military training, without, however, being able to improve their frequency and the actual involvement of young people into the program. Students did participate, although without any enthusiasm, for fear of school repercussions.

Regarding the Sentinels' program and activities, "The Country's Sentinel" imitated the Legionary Movement, and other similar organizations from Europe: the cult of the leader, the working camps, the legionary cooperatives, a rigorous

38 (1940). Straja Țării - cinci ani de activitate (1935-1940) (The Country's Sentinel. Five Years of Activity (1935-1940)). Bucharest: Editura Cartea Românească, pp. 211-214.

39 “Straja Țării”" (“The Country’s Sentinel”), Bucharest, no. 1-2, 1939, pp. 90, 123; no. 1-2, 1940, p. 55; "Almanahul Străjerilor" ("The Sentinels' Almanach”), Bucharest, no. 3-6, 1939, p. 239; (1940). Straja Țării - cinci ani de activitate (1935-1940) (The Country's Sentinel. Five Years of Activity (1935-1940)). Bucharest: Editura Cartea Românească, p. 226

40 (1940). Straja Țării - cinci ani de activitate (1935-1940) (The Country's Sentinel. Five Years of Activity (1935-1940)). Bucharest: Editura Cartea Românească, p. 216. 
program, youth indoctrination, and the religious spirit. The King also tried to impose "The Country's Sentinel" the mystical spirit, specific to the Legionaries. He failed, mainly due to the fact that participation was compulsory, youngsters being forced to participate, but also because the King did not have Zelea Codreanu's charisma and his personal life was not a moral example in terms of public life. Due to their behaviour, greeting and elements similar to those of the Legionary Movement, the Sentinels were sometimes taken for Legionaries by the police, although their uniforms were different. Copying a series of elements from the Legionaries was intended to create confusion among the young people and thus persuade them that there was no reason to join the Legion. Many of the teachers who had become trainers in "The Country's Sentinel" secretly sympathized with the Legionary Movement, thus, sharing their right-oriented ideas in a legal form under the Sentinel's curtain.

"The Country's Sentinel" became a mass organization, comprising all the young people up to the age of 21, as well as teachers and priests. This organization would stop functioning once the authoritarian monarchy regime of Charles II was dissolved, after his abdication on September $6^{\text {th }} 1940$.

The organization model of the Country's Sentinel would be later imitated by the Communists, young people aged between 7 and 14 being enrolled into "The Pioneers' Organization".

\section{REFERENCES}

The Central Historical National Archives, Royal Household Fund, 1934-1940.

BRUJA, Radu Florian, Carol al II-lea şi partidul unic: Frontul Renaşterii Naționale (Charles II and the Single Party: the National Rebirth Front), Junimea, Iasi, 2006.

ENESCU BugheA, Sunt străjer! ...cartea năzuințelor tinereşti (I am a Sentinel! ... The Book of Youthful Aspirations), Bucharest, 1936.

HEINEN, Armin, Legiunea "Arhanghelul Mihail". O contribuție la problema fascismului international, (The Legion of "The Archangel Michael". A contribution to the Isssue of International Fascism), Humanitas, Bucharest, 1999.

GABREA, Iosif, Şcoala şi străjeria în pregătirea tineretului (The School and the Sentinels in Youth Training), Bucharest, 1936.

GoIA, A.S., Şcoala de comandanți de la Breaza (The Commanders' School in Breaza), Cluj, 1934.

GoIA, A.S., Taberele de muncă cercetăşsesti la sate (The Scout Work Camps in Villages), Bucharest, 1936.

SIDOROvicI, Teofil, Gh., Enescu Bughea, C., Straja Țării. O credință şi un avânt (The Sentinels of the Country. Faith and Impetuosity), Bucharest, 1937.

Sidorovici, Teofil Gh., Carnetul străjerului (The Sentinel's Notebook), Bucharest, 1939.

SIDOROVICI, Teofil Gh., Pe căile renaşterii (On the Path of Rebirth), Bucharest, 1940. 
Strecovschi, Toma, I., Cuibul străjeresc. Contribuții (The Sentinels' Nest. Contributions), Bucharest, 1939.

ŞOIMESCU, Stefan, Cu marele străjer - curent de viață nouă (Along with the Great Sentinel - a New Life Trend), Bucharest, 1939.

ŞOIMESCU, Stefan, Doctrină, metodă sau curent de viață? (Doctrine, Method, or Way of Life?), Bucharest, 1940. 
Forms of Political and Para-military Youth Enrollment in Romania. Case Survey: The Country's Sentinel...

Annex 1. The King Charles the 2nd of Hohenzollern 1930 - 1940

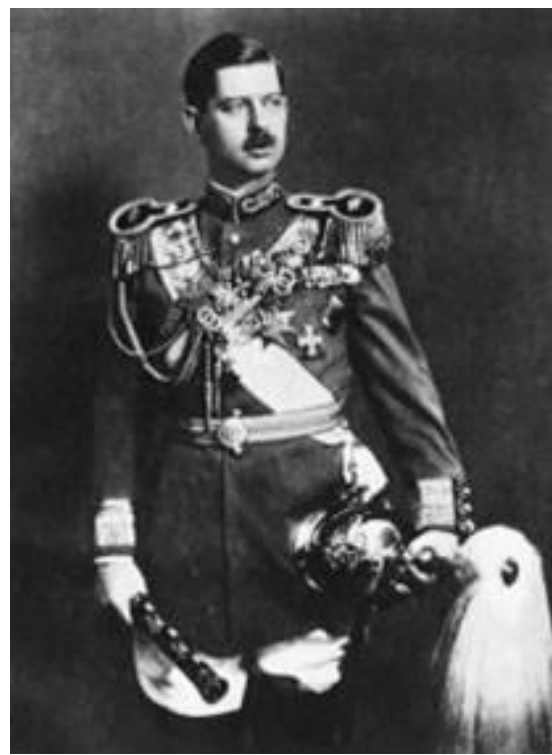

Annex 2. Teofil Sidorovici and his sentinels

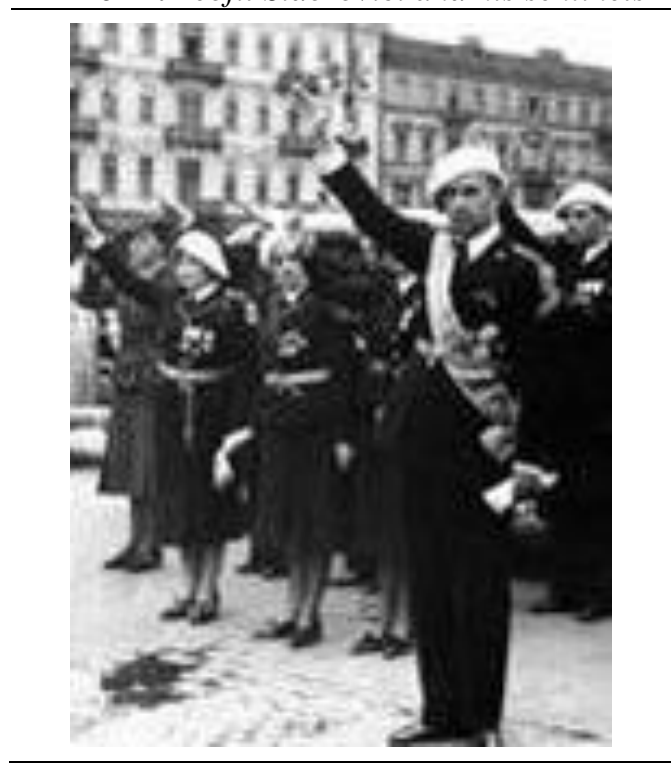


Annex 3. King Charles the 2nd among the sentinels of Cernatu village (Braşov County).

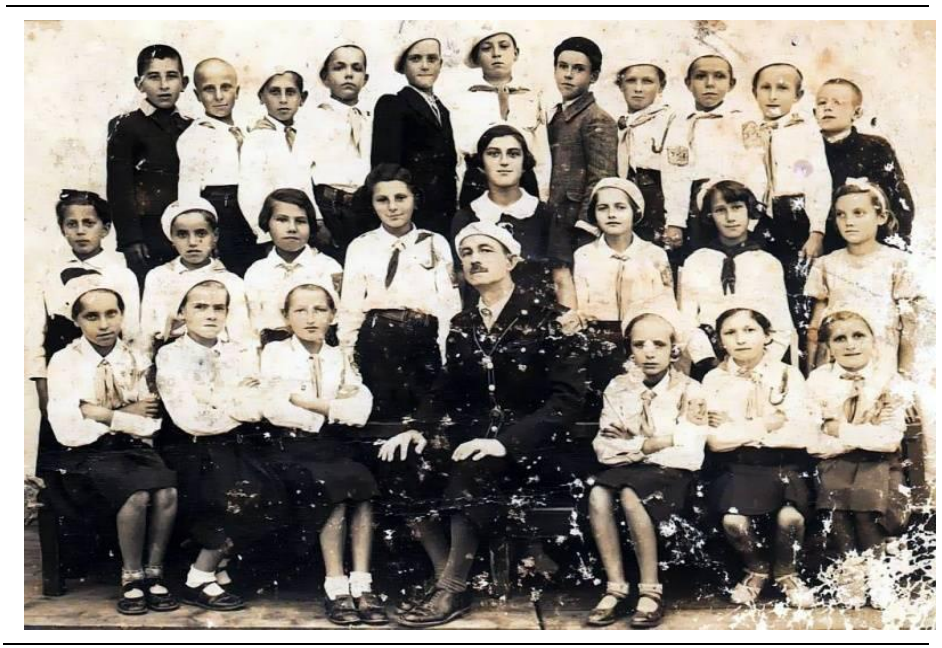

Annex 4. A student's notebook with the face of "The Great Sentinel" and two sentinels saluting.

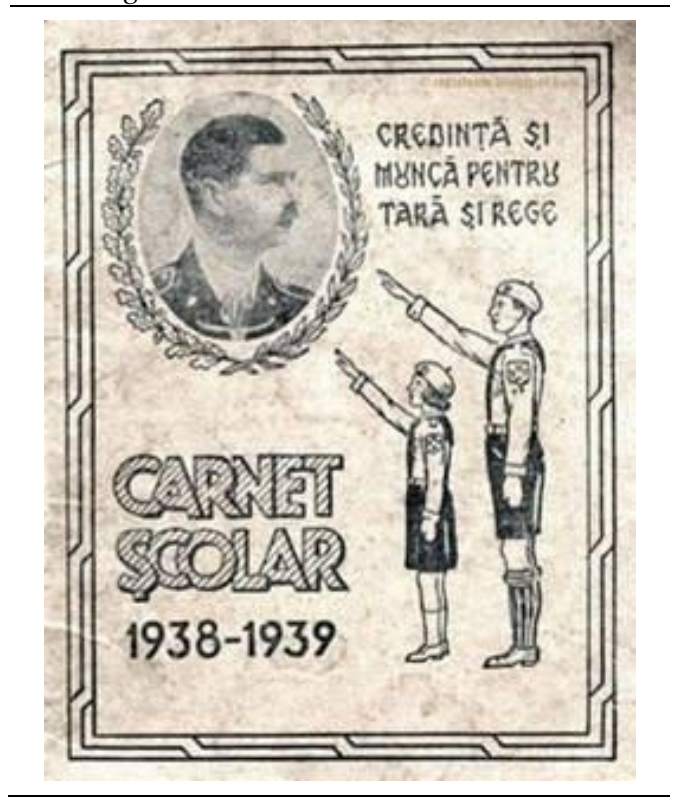


Forms of Political and Para-military Youth Enrollment in Romania. Case Survey: The Country's Sentinel...

Annex 5. The Great Sentinel, Charles the 2nd, at inauguration of the sentinels' parade on a stadium in Bucharest on the 8th of June 1937

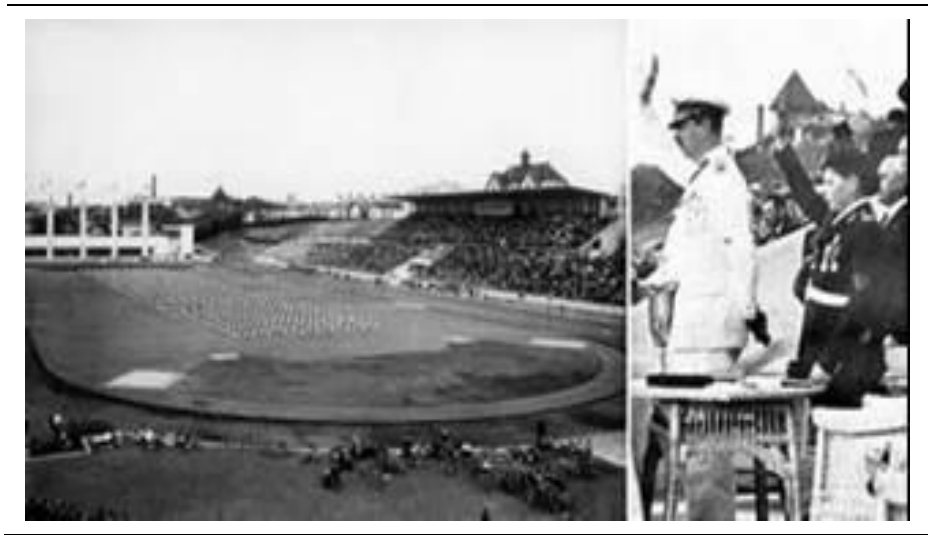

Annex 6. The sentinels organization of the secondary school "Vasile Lupu" in Iasi, singing songs at radio for "The Sentinels' Hour" (1939)

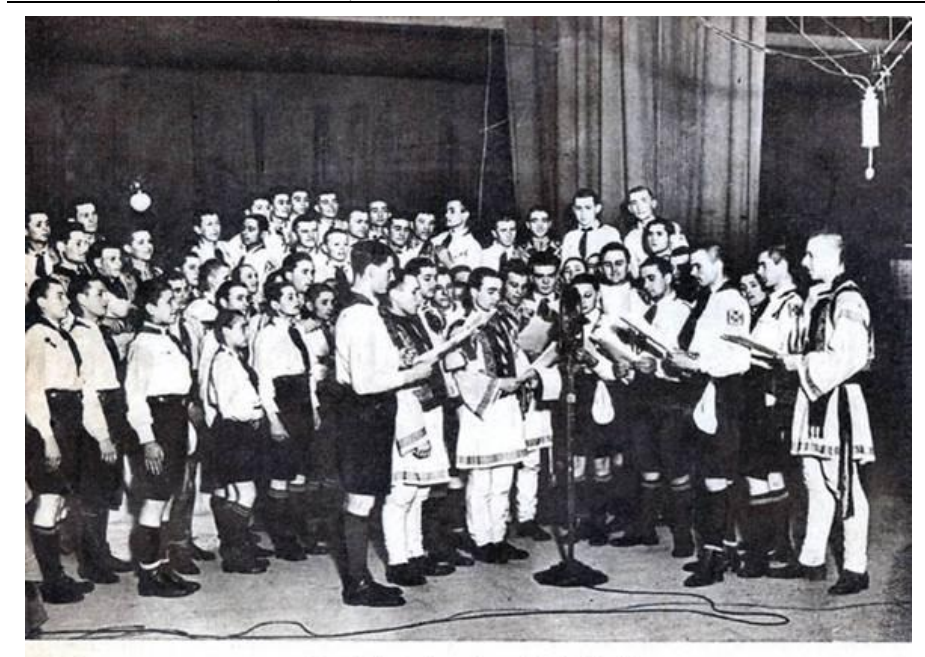

○ emisiune 10 ..Oro sirōierilor" 